\title{
The effect of climate forcing on numerical simulations of the Cordilleran ice sheet at the Last Glacial Maximum
}

\author{
J. Seguinot ${ }^{1}$, C. Khroulev ${ }^{2}$, I. Rogozhina ${ }^{3}$, A. P. Stroeven ${ }^{1}$, and Q. Zhang ${ }^{1}$ \\ ${ }^{1}$ Department of Physical Geography and Quaternary Geology and the Bolin Centre for Climate Research, Stockholm \\ University, Stockholm, Sweden \\ ${ }^{2}$ Geophysical Institute, University of Alaska Fairbanks, Fairbanks, AK, USA \\ ${ }^{3}$ Helmholtz Centre Potsdam, GFZ German Research Centre for Geosciences, Potsdam, Germany \\ Correspondence to: J. Seguinot (julien.seguinot@natgeo.su.se)
}

Received: 22 November 2013 - Published in The Cryosphere Discuss.: 23 December 2013

Revised: 17 April 2014 - Accepted: 4 May 2014 - Published: 23 June 2014

\begin{abstract}
We present an ensemble of numerical simulations of the Cordilleran ice sheet during the Last Glacial Maximum performed with the Parallel Ice Sheet Model (PISM), applying temperature offsets to the present-day climatologies from five different data sets. Monthly mean surface air temperature and precipitation from WorldClim, the NCEP/NCAR reanalysis, the ERA-Interim reanalysis, the Climate Forecast System Reanalysis and the North American Regional Reanalysis are used to compute surface mass balance in a positive degree-day model. Modelled ice sheet outlines and volumes appear highly sensitive to the choice of climate forcing. For three of the four reanalysis data sets used, differences in precipitation are the major source for discrepancies between model results. We assess model performance against a geomorphological reconstruction of the ice margin at the Last Glacial Maximum, and suggest that part of the mismatch is due to unresolved orographic precipitation effects caused by the coarse resolution of reanalysis data. The best match between model output and the reconstructed ice margin is obtained using the high-resolution North American Regional Reanalysis, which we retain for simulations of the Cordilleran ice sheet in the future.
\end{abstract}

\section{Introduction}

At the Last Glacial Maximum (LGM), glaciers of a comparable size to the present-day Greenland and Antarctic ice sheets covered parts of North America (Laurentide, Cordilleran and Innuitian ice sheets) and northern Eurasia (Fennoscandian and Eurasian ice sheets). Numerical modelling of these former ice masses allows for a comparison between glaciological theories embedded in the models and geomorphological traces underpinning palaeo-glaciological reconstructions. Yet, a major obstacle in this exercise resides in large uncertainties concerning the climate forcing, typically atmospheric temperature and precipitation, required as input to numerical glacier models (Hebeler et al., 2008). This includes uncertainty in the representation of Earth's present climate in regions of poor station coverage, and even larger uncertainty concerning accurate reconstructions of past climate change.

Arguably the most physically sound way to force an ice sheet model for simulations of glacial history is to couple it with a general circulation model (GCM; Yoshimori et al., 2001; Calov et al., 2002; Abe-Ouchi et al., 2007; Charbit et al., 2013). However the computational demand of GCMs is such that only models of intermediate complexity can run on the timescales of tens of thousands of years characteristic of ice sheet growth and decay.

Climatologies obtained from GCM palaeo-climate simulations such as produced within the Paleoclimate Modelling Intercomparison Project (PMIP; Joussaume and Taylor, 1995) provide perhaps a more reasonable representation of past climate. However, as such climatologies are only available for specific periods of time, using them as climate forcing for an ice sheet model requires either an assumption of steady-state ice sheet response to climatic fluctuations (Huybrechts and T'siobbel, 1996), or interpolation through time between climatologies from different periods, which can be linear (Charbit et al., 2002), or modulated by a "glacial index" weighting 


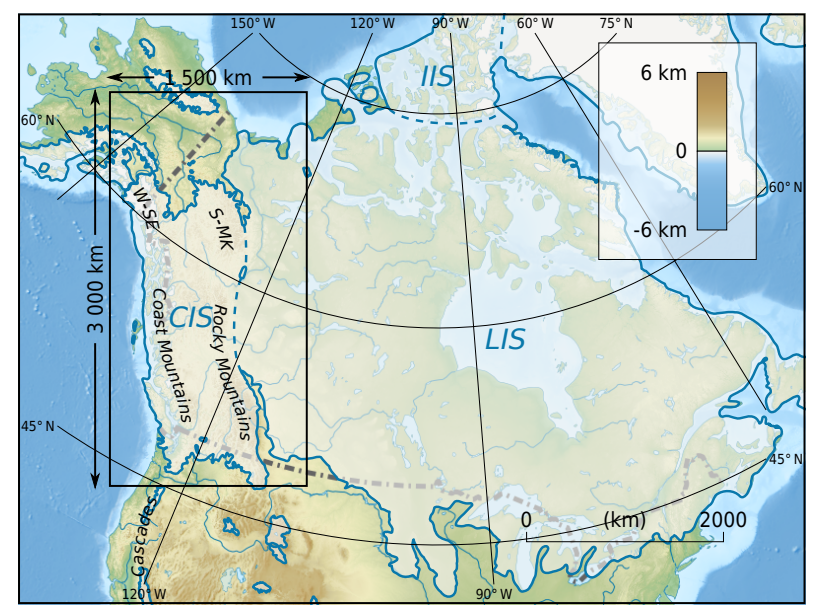

Figure 1. Shaded relief map of northern North America with the extent of the Cordilleran (CIS), Laurentide (LIS) and Innuitian (IIS) ice sheets at $14{ }^{14} \mathrm{C}$ kyr BP (16.8 cal kyr BP) (Dyke, 2004). While this age denotes the LIS after retreat from its LGM, it closely corresponds to the LGM extent of most of the Cordilleran ice sheet (Porter and Swanson, 1998; Dyke, 2004; Stroeven et al., 2010). The rectangular box denotes the modelling domain of the Cordilleran ice sheet of 1500 by $3000 \mathrm{~km}$. Major mountain ranges covered by the ice sheet include the Wrangell and Saint Elias mountains (W$\mathrm{SE}$ ), the Selwyn and MacKenzie mountains (S-MK), the Coast Mountains and the Rocky Mountains. The background map consists of ETOPO1 (Amante and Eakins, 2009) and Natural Earth Data (Patterson and Kelso, 2010) and was assembled with GRASS GIS (Neteler et al., 2011).

function derived from ice core $\delta^{18} \mathrm{O}$ records (Marshall and Clarke, 1999; Tarasov and Peltier, 2004; Zweck and Huybrechts, 2005; Gregoire et al., 2012). An important drawback in this approach is that GCM palaeo-climate simulations themselves rely on an accurate description of the global surface topography and therefore include global ice sheet reconstructions such as ICE-4G (Peltier, 1994) for their surface topographic boundary condition. This condition could potentially exert influence on subsequently modelled ice sheet geometries, and particularly glacier extent.

However, avoiding this circular dependence requires simplifying assumptions regarding Earth's past climate. Such studies include energy balance modelling approaches (Tarasov and Peltier, 1997) and geographic parametrisations of surface mass balance (Robert, 1991) or climate forcing (Johnson and Fastook, 2002). Alternatively, temperature offset methods (Greve et al., 1999; Bintanja et al., 2005) make use of the high level of detail available in present climate data sets such as gridded observation data sets, GCM output or reanalyses, while using simplifying representations of past climate deviations from the present state.

Here, we propose to address some of the uncertainties concerning climate forcing of numerical glacier models by evaluating the responses of a numerical model, in terms of glacier extent, to inputs from several climate data sets. This is not entirely a new approach as a few studies of this kind are presently available. Quiquet et al. (2012), for example, assessed the sensitivity of a Greenland Ice Sheet model to various climate forcing fields, including a regional parametrisation by Fausto et al. (2009a), output from several GCMs and an atmospheric reanalysis. Rodgers et al. (2004) and Charbit et al. (2007) tested the sensitivity of a model of Northern Hemisphere ice sheets to climate forcing from different PMIP LGM simulations. Although using different set-ups, all three studies demonstrate the very large sensitivity of ice sheet models to the choice of climate forcing data used. To limit the degrees of freedom in our model and obtain results independent of palaeo-ice-sheet reconstructions such as ICE$4 \mathrm{G}$, we use a simple temperature offset similar to the approaches by Greve et al. (1999) and Bintanja et al. (2005) and assess ice sheet model sensitivity to the choice of present-day climate data. Hence, rather than using GCM output, we force our model with climate reanalysis data, which builds on observational information through data assimilation (Bengtsson et al., 2007). Furthermore, we focus our study regionally on the former Cordilleran ice sheet in western North America.

The Cordilleran ice sheet (Fig. 1) covered an area that presently experiences strong regional variations in climate. From a numerical modelling perspective, it is one of the least studied palaeo-ice-sheets of the Northern Hemisphere, despite the fact that significant stratigraphical, geomorphological, and chronological data is available to constrain its extent (Jackson and Clague, 1991; Porter and Swanson, 1998; Duk-Rodkin, 1999; Dyke, 2004; Kaufman and Manley, 2004; Kleman et al., 2010; Stroeven et al., 2010, 2014; Margold et al., 2011). The Cordilleran ice sheet has previously been modelled as part of efforts to simulate ice sheets in North America (Marshall and Clarke, 1999; Calov et al., 2002; Tarasov and Peltier, 1997, 2004; Gregoire et al., 2012), the Northern Hemisphere (Huybrechts and T'siobbel, 1996; Greve et al., 1999; Charbit et al., 2002, 2007, 2013; Johnson and Fastook, 2002; Rodgers et al., 2004; Bintanja et al., 2005; Zweck and Huybrechts, 2005; Abe-Ouchi et al., 2007) and world wide (Yoshimori et al., 2001). While these studies generally reproduce the magnitude of North American glaciation at LGM reasonably well, there exists a tendency in the simulations that are independent of ice sheet reconstructions such as the ICE-4G to predict excessive ice cover in parts of northern Yukon Territory and interior Alaska that have remained ice free throughout the Pleistocene (DukRodkin, 1999; Kaufman and Manley, 2004).

Here we use PISM, a Parallel Ice Sheet Model (the PISM authors, 2013), to simulate the extent and thickness of the Cordilleran ice sheet at the LGM (Fig. 1). We force our model with multiple climate data sets and compare the modelled ice extent to a geomorphological reconstruction of the LGM ice sheet margin by Dyke (2004). We aim to determine the climate data set which is most suited for simulation of the Cordilleran ice sheet and to use as input for future, transient studies over a glacial cycle. 


\section{Model set-up}

Given basal topography, sea level, geothermal heat flux and climate forcing, the model computes ice extent and thickness, its thermal and dynamic state, and the associated lithospheric response. Our modelling domain encompasses the entire area covered by the Cordilleran ice sheet at LGM including independent ice growing on the western Alaskan ranges and the Brooks Range, and intermediate expanses of ice-free terrain in northern Yukon Territory and interior Alaska (Fig. 1).

As we aim to model glacial inception and growth of the Cordilleran ice sheet towards a configuration as last attained during the LGM, we mimic palaeo-climatic conditions by applying constant temperature offsets homogeneously over the modelling domain. Each simulation starts from ice-free conditions and runs for $10 \mathrm{kyr}$, a time interval representative of the rapid build-up of the last Cordilleran ice sheet from nearly ice free to full glacial conditions (Clague, 1989; Stroeven et al., 2010). Our simulations are performed in parallel on 32 cores at the Swedish National Supercomputing Center.

\subsection{Ice thermodynamics}

The central part of an ice sheet model consists of the computation of flow velocity which itself depends on temperature. PISM is a shallow model, which implies that the balance of stresses is approximated based on their predominant components. On the other hand, the model is polythermal: it accounts for differences in temperature and softness within the ice column.

The shallow shelf approximation (SSA) is used as a "sliding law" for the shallow ice approximation (SIA) (Bueler and Brown, 2009; Winkelmann et al., 2011). SIA and SSA velocities are computed by finite difference methods on a $10 \mathrm{~km}$ resolution horizontal grid of 300 by 150 points (the modelling domain). Ice softness depends on temperature and water content through an enthalpy formulation (Aschwanden and Blatter, 2009; Aschwanden et al., 2012). Enthalpy is computed in three dimensions in up to 51 irregularly spaced layers within the ice, and temperature is additionally computed in 11 regularly spaced layers in bedrock to a depth of $1 \mathrm{~km}$. Surface air temperature from the climate forcing provides the upper boundary condition to the ice enthalpy model, and a geothermal heat flux of $70 \mathrm{~mW} \mathrm{~m}^{-2}$ provides the lower boundary condition to the bedrock thermal model. Although this uniform value does not account for the high-spatial geothermal variability in the region, it is on average representative of available heat flow measurements (Artemieva and Mooney, 2001; Blackwell and Richards, 2004). Whereas spatial variations in the geothermal heat flux may significantly affect basal conditions (Pattyn, 2010), this study focuses on reconstructing the former extent of the Cordilleran ice sheet, on which it has relatively little effect (Rogozhina et al., 2012).
A pseudo-plastic sliding law (Aschwanden et al., 2013) relates the bed-parallel shear stress and the sliding velocity. The yield stress is modelled using the Mohr-Coulomb criterion. The till friction angle $\phi$ varies from 10 to $30^{\circ}$. It is computed once at the beginning of the run, as a function of modern bed elevation, with lowest values occurring at low elevations:

$\phi= \begin{cases}10 & \text { for } z<0 \\ z / 10+10 & \text { for } 0<z<200 \\ 30 & \text { for } 200<z,\end{cases}$

where $\phi$ is given in degrees and $z$ in metres above current sea level. This model thus accounts for a weakening of till associated with the presence of marine sediments (Martin et al., 2011; Aschwanden et al., 2013). Because the distribution of marine sediments is assumed constant throughout the run, the till friction angle $\phi$ is not affected by changes in bed elevation. Basal topography (Fig. 2) is derived from the ETOPO1 combined topography and bathymetry data set with a resolution of 1 arcmin (Amante and Eakins, 2009).

Sea level is lowered by $120 \mathrm{~m}$ and basal topography responds to ice load following a bedrock deformation model that includes point-wise isostasy, elastic lithosphere flexure and viscous mantle deformation in a semi-infinite halfspace (Lingle and Clark, 1985; Bueler et al., 2007). It uses a lithosphere density of $3300 \mathrm{~kg} \mathrm{~m}^{-3}$, a flexural rigidity of $5 \times 10^{24} \mathrm{Nm}$ and a mantle viscosity of $1 \times 10^{21} \mathrm{~Pa}$ s. Due to the high mantle viscosity, there exists a time lag between ice sheet growth and isostatic bedrock response.

\subsection{Surface mass balance}

Ice surface accumulation and ablation are computed from monthly mean surface air temperature and monthly precipitation by a temperature-index (positive degree day) model (Hock, 2003). Ice accumulation is equal to precipitation when temperature is below $0^{\circ} \mathrm{C}$, and decreases to zero linearly with temperature between 0 and $2^{\circ} \mathrm{C}$. Ice ablation is computed from the number of positive degree days, defined as the integral of temperatures above $0{ }^{\circ} \mathrm{C}$ in one year.

The positive degree-day integral (Calov and Greve, 2005) is numerically approximated using week-long sub-intervals. It accounts for temperature variability assuming a normal distribution along a central (input) value. The temperature standard deviation is a constant model parameter and was assigned a value of $3.07^{\circ} \mathrm{C}$, which corresponds to the mean summer (JJA), model domain-averaged monthly standard deviation of daily mean temperature from monthly mean temperature, as computed from North American Regional Reanalysis data (Mesinger et al., 2006) in a manner similar to Seguinot (2013). The ablation model incorporates degree-day factors of $3.04 \mathrm{~mm}^{\circ} \mathrm{C}^{-1} \mathrm{day}^{-1}$ for snow and $4.59 \mathrm{~mm}^{\circ} \mathrm{C}^{-1} \mathrm{day}^{-1}$ for ice, as derived from mass-balance measurements on contemporary glaciers from the Coast 

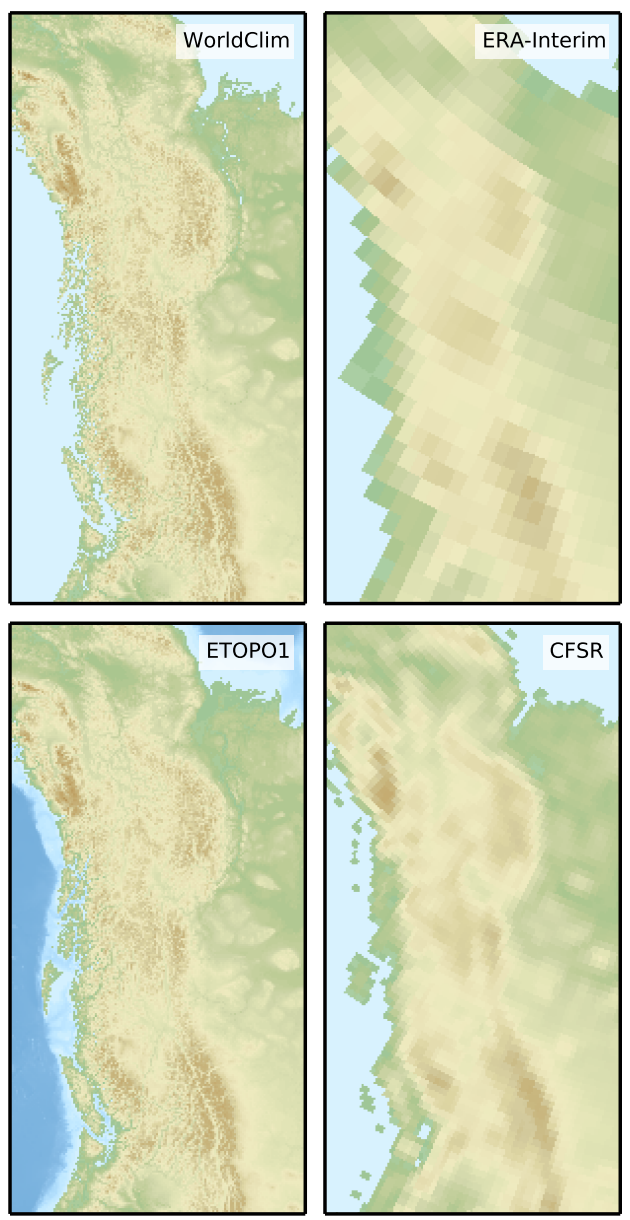

6000

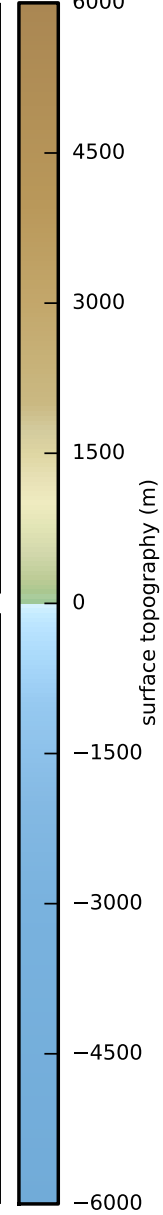

Figure 2. Topography maps from WorldClim (Hijmans et al., 2005), ERA-Interim reanalysis (Dee et al., 2011), North American Regional Reanalysis (NARR; Mesinger et al., 2006), ETOPO1 (Amante and Eakins, 2009), Climate Forecast System Reanalysis (CFSR; Saha et al., 2010), and NCEP/NCAR reanalysis (Kalnay et al., 1996). Whereas ETOPO1 is used as basal topography for the ice sheet model, all other data are used as a reference for temperature lapse-rate corrections. Figures 2-16 are drawn using Matplotlib (Hunter, 2007).

Mountains and Rocky Mountains in British Columbia (Shea et al., 2009).

\subsection{Air temperature corrections}

Prior to surface mass balance computation, the model dynamically applies a lapse-rate correction to surface air temperature. This correction accounts for the evolution of ice thickness on the one hand, and differences between the climate forcing reference topography and the ice flow model basal topography on the other hand. It uses a reference topography distinct from the modelled basal topography and specific to each climate forcing data set (Fig. 2). An annual lapse rate of $6^{\circ} \mathrm{C} \mathrm{km}^{-1}$ is used in all simulations. No corrections apply to precipitation changes with elevation.

\section{Climate forcing}

Our climate forcing consists of monthly climatologies of surface air temperature and precipitation obtained from one observational data set, three global reanalyses and one regional reanalysis.

\subsection{Observational data: WorldClim}

WorldClim is a high-resolution global climate data set built from meteorological observations (Hijmans et al., 2005). It was built by applying a spatial interpolation between a large set of measurements taken at terrestrial weather stations worldwide, using SRTM (Jarvis et al., 2005) and GTOPO30 elevation data (Gesch et al., 1999). This data set provides a resolution much higher than attained by circulation models, however its reliability is variable due to the highly inhomogeneous distribution of measurements (Hijmans et al., 2005). 

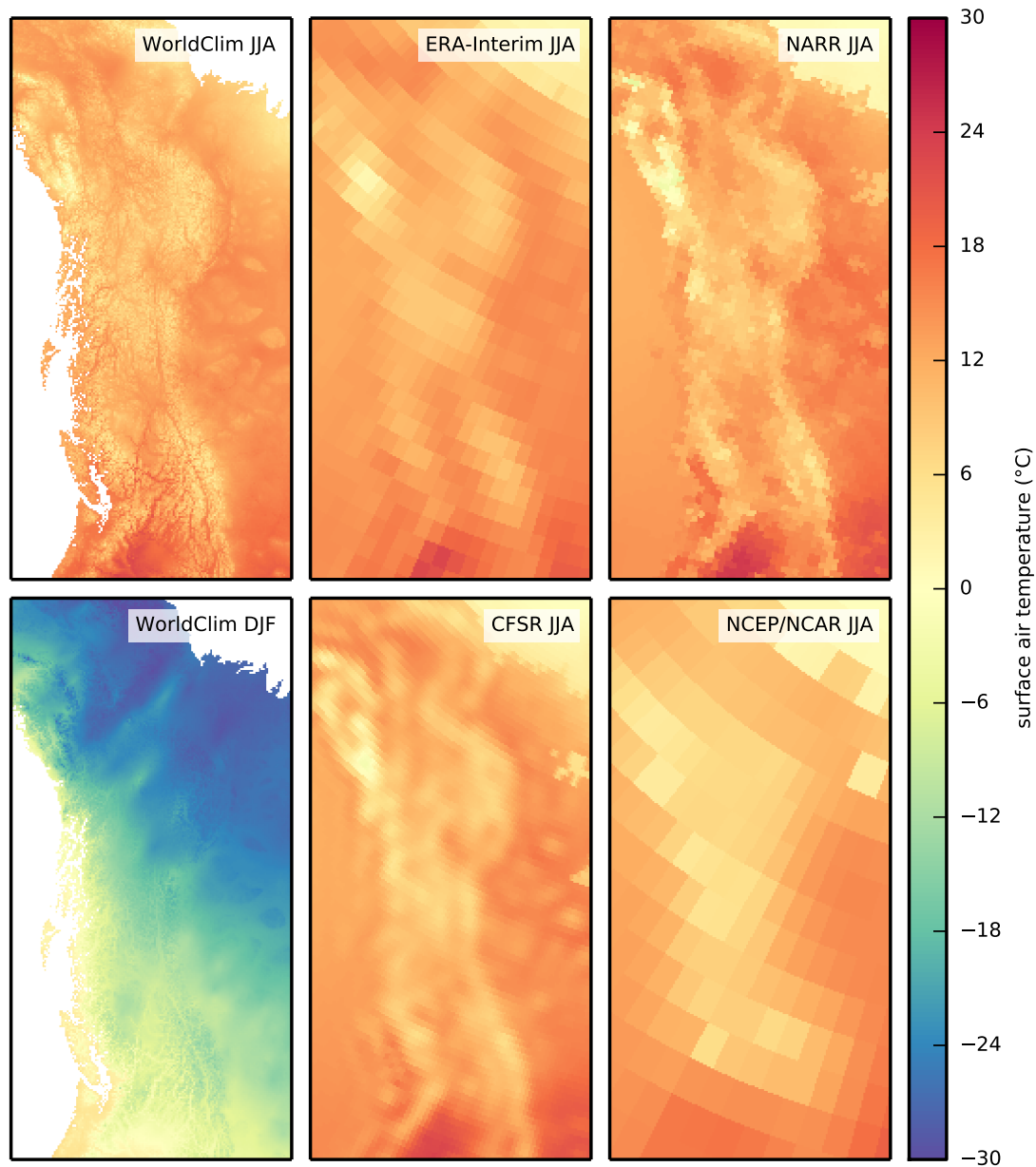

Figure 3. Summer (JJA) and winter (DJF) temperature maps from WorldClim (Hijmans et al., 2005), and summer (JJA) temperature maps from ERA-Interim reanalysis (Dee et al., 2011), North American Regional Reanalysis (NARR; Mesinger et al., 2006), Climate Forecast System Reanalysis (CFSR; Saha et al., 2010), and NCEP/NCAR reanalysis (Kalnay et al., 1996) climatologies.

Table 1. Characteristics of reanalysis climatologies used to inform the mass balance component of PISM.

\begin{tabular}{lcccc}
\hline Reanalysis & Spatial coverage & Averaging period & Resolution & Description \\
\hline NCEP/NCAR & global & $1981-2010$ & $1.875^{\circ}$ & Kalnay et al. (1996) \\
ERA-Interim & global & $1979-2011$ & $1.000^{\circ}$ & Dee et al. (2011) \\
CFSR & global & $1979-2010$ & $0.325^{\circ}$ & Saha et al. (2010) \\
NARR & North America & $1979-2000$ & $32 \mathrm{~km}$ & Mesinger et al. (2006) \\
\hline
\end{tabular}

Within our modelling domain, the spatial distributions of summer (JJA) and winter (DJF) air surface temperatures in WorldClim generally show a decrease of temperature from south to north (JJA) and from south-west to north-east (DJF), such that regions further inland experience colder winters (Fig. 3). It should be noted that temperature gradients are much stronger in winter than in summer. Temperature rises well above zero during the summer months over the entire modelling domain, except for the highest mountain peaks, and even regions where mean annual temperatures are well below freezing point experience warm summers. In other words, there is a strong contrast in seasonality between coastal temperate-climate and inland continental-climate regions.

The spatial distribution of JJA and DJF mean precipitation rates in WorldClim reveals a strong precipitation decline beyond the coastal regions (Fig. 4), primarily as a result of the continuous orographic barrier formed by the Wrangell and Saint Elias mountains, the Coast Mountains and the Cascades (Fig. 1). A less pronounced precipitation peak is also visible over the interior ranges. From an ice-sheet massbalance point of view, these heterogeneities become even 

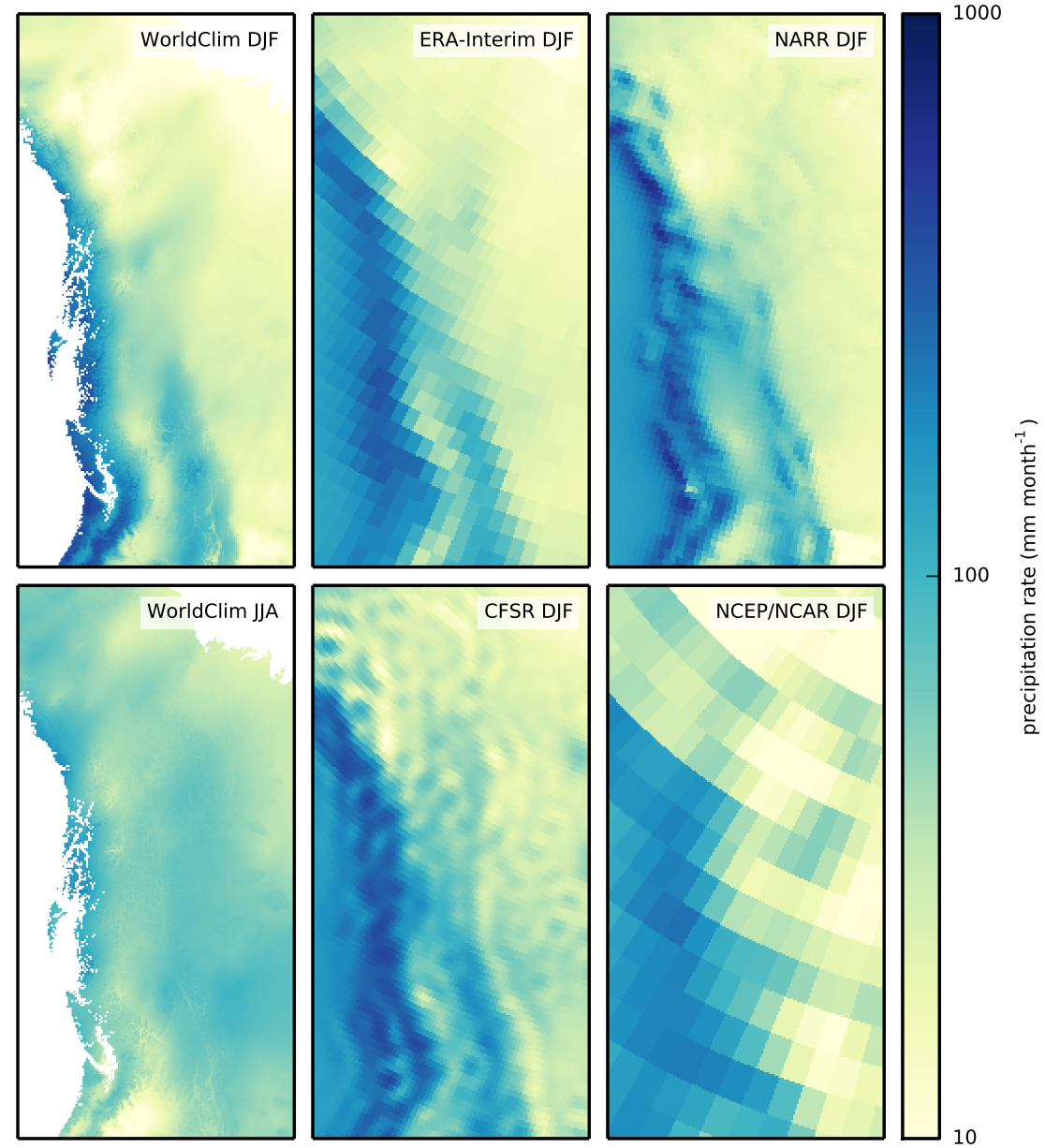

Figure 4. Winter (DJF) and summer (JJA) precipitation maps from WorldClim (Hijmans et al., 2005), and winter (DFJ) precipitation maps from ERA-Interim reanalysis (Dee et al., 2011), North American Regional Reanalysis (NARR; Mesinger et al., 2006), Climate Forecast System Reanalysis (CFSR; Saha et al., 2010), and NCEP/NCAR reanalysis (Kalnay et al., 1996) climatologies. Additional forcing data was prepared to correct for wave-like precipitation artefacts in CFSR (Sect. 3).

stronger due to the difference in timing of the precipitation peak through the year. Whereas coastal regions experience most precipitation as snow during the accumulation season (DJF), inland regions experience dry winters and most of the annual precipitation consequently falls as rain during the ablation season (JJA).

In regions such as the northern Yukon Territory and interior Alaska, dry winters and warm summers prohibit ice to accumulate and glaciers to form, despite strongly negative mean annual temperatures. In order to account for these strong gradients in seasonality, we use monthly rather than annual averages of temperature and precipitation to drive the ice sheet model.

There are two problems inherent to the use of WorldClim data in our study area. First, the density of weather stations used by WorldClim in the northern American Cordillera is highly inhomogeneous. Although good coverage exists for the southern part of our modelling domain, several hundred kilometres can separate neighbouring stations in the north
(Hijmans et al., 2005). Second, WorldClim lacks data offshore, which would have been particularly useful over the Pacific continental shelf which was partly covered by ice during the LGM (Jackson and Clague, 1991).

\subsection{Reanalysis data: NCEP/NCAR, ERA-Interim, CFSR and NARR}

In addition to the WorldClim data, we use surface air temperatures and precipitation rates from three global atmospheric reanalyses and one regional atmospheric reanalysis to inform the mass balance routine of PISM: the NCEP/NCAR reanalysis (Kalnay et al., 1996), the ERA-Interim reanalysis (Dee et al., 2011), the Climate Forecast System Reanalysis (CFSR; Saha et al., 2010), and the North American Regional Reanalysis (NARR; Mesinger et al., 2006). Monthly climatologies from NCEP/NCAR and NARR reanalyses were provided by the NOAA/OAR/ESRL Physical Sciences Division (2013), whereas monthly climatologies from the ERA-Interim and 
CFSR reanalyses were computed from their monthly mean time series (Table 1).

The spatial distributions of JJA air surface temperatures and DJF precipitation rates from the four reanalysis climatologies are shown in Figs. 3 and 4. Summer temperature and winter precipitation are most relevant to the glacier model as they drive summer melt and winter accumulation, respectively. Because reanalyses include observational information through data assimilation, they are closer to observations than pure GCMs in densely monitored regions, such as the southern part of our modelling domain (Bengtsson et al., 2007). On the other hand, the atmospheric physics embedded in the models provide more realistic output than obtained by spatial interpolation in sparsely monitored regions, such as the northern part of our modelling domain.

\subsection{Preprocessing and lapse-rate corrections}

WorldClim, NCEP/NCAR, ERA-Interim, CFSR and NARR climatologies were re-projected to the Canadian Atlas Lambert conformal conic projection (EPSG code 3978) and bilinearly interpolated to the $10 \mathrm{~km}$ resolution model grid using the module r.proj from GRASS GIS (Neteler et al., 2011). In addition, WorldClim data was extrapolated to cover grid points in the ocean using the nearest-neighbour algorithm (Oliphant, 2007). Note that here we choose to present original rather than interpolated data, in order to highlight differences between data sets related to spatial resolution (Figs. 3 and 4).

The CFSR climatology presents wave-like artefacts in its precipitation field (Fig. 4). These are a common feature in GCM simulations due to the failure of spectral models to resolve the very local nature of topography-induced precipitation events, which becomes particularly visible in the highresolution, less spatially smoothed data. Therefore, an alternative forcing was prepared for CFSR by smoothing its precipitation field. This was achieved by averaging data locally in a circular kernel of 7 pixels in diameter prior to reprojection using the module r.neighbors from GRASS GIS (Neteler et al., 2011). Finally, input files for PISM were prepared using netCDF4-Python (Whitaker, 2014).

\section{Results}

Using WorldClim, NCEP/NCAR, ERA-Interim, CFSR (smoothed and original data sets) and NARR input climatologies as climate forcing, we run 66 simulations of glacial inception and growth of the Cordilleran ice sheet over $10 \mathrm{kyr}$ using temperature offsets ranging from -10 to $0{ }^{\circ} \mathrm{C}$. Significant differences in patterns of ice sheet growth, final glacial extent, and volume are attained (Figs. 5-7).

Across the range of temperature offsets used, final glaciated area and final ice volume differ widely between different input climatologies (Fig. 5). For instance, using a $-5{ }^{\circ} \mathrm{C}$ temperature offset, final glaciated area differs between WorldClim and CFSR forcing by a factor of 6 and final volume by a factor of 12 (Fig. 5). For particular temperature offset values, given input climatologies result in similar final glaciated areas and ice volumes, yet regional patterns are different (Fig. 6).

Under present climate $\left(0^{\circ} \mathrm{C}\right.$ offset $)$, WorldClim, ERAInterim and NARR forcing produce local ice caps in areas presently glaciated (Fig. 6). These results are fairly consistent with contemporary ice distribution, although both the $10 \mathrm{~km}$ horizontal resolution and the occurrence of glaciers and ice caps surface topographies in the ETOPO1 data set used for basal topography prevent a meaningful detailed comparison. CFSR forcing, on the other hand, yields continuous ice cover over the northern Coast Mountains, and NCEP/NCAR forcing results in ice sheet growth, both of which are largely inconsistent with the present state of glaciation. At the opposite side of the temperature offset range, it can be noted that both the NCEP/NCAR and CFSR forcing produce oversized ice sheets whose extents are primarily restricted by the domain boundaries (Fig. 6). The smoothing of CFSR precipitation yields an insignificant effect on the resulting ice sheet geometry.

To contrast the effect of the six different input climatologies, we plot simulations using a $-5^{\circ} \mathrm{C}$ temperature offset (Fig. 7). The magnitude of glaciation differs dramatically from one climate forcing to another. Whereas the NCEP/NCAR and CFSR climatologies produce a large ice sheet that covers most of the model domain (Fig. 7, lower panels), WorldClim, ERA-Interim and NARR climatologies lead to a more restrictive ice cover (Fig. 7, upper panels). The WorldClim run only resulted in the growth of mountain ice caps bounded to the highest topography.

\section{Discussion}

These simulations of the LGM Cordilleran ice sheet show a very large sensitivity to the choice of climate forcing data used (Figs. 5-7). To understand the origin of the discrepancies between model results, we quantify differences in surface air temperature and precipitation rate between the input climatologies and test their effect on the ice sheet model. We then compare our findings to a geomorphological reconstruction of the LGM Cordilleran ice sheet margin, and discuss some of the key assumptions of this study.

\subsection{Comparison of forcing climatologies}

As previously outlined, significant differences in the distribution of winter (DJF) precipitation and summer (JJA) temperature, which are the predominant controls on accumulation and melt at the modelled ice sheet surface, exist between data sets (Figs. 2-4). In this section we use the WorldClim climatology, which is derived from observations, as 


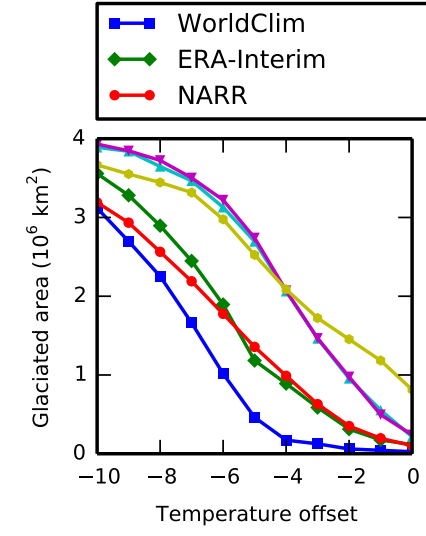

$\begin{aligned} & \text { smoothed CFSR } \\ & \text { CFSR } \\ & \text { NCEP/NCAR }\end{aligned}$

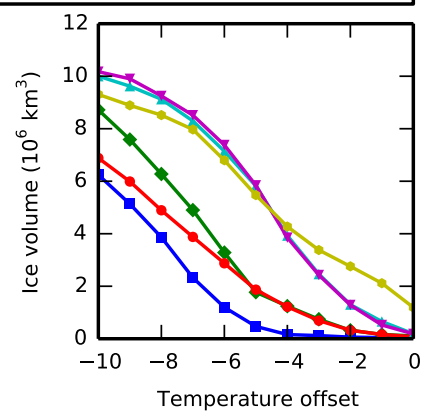

Figure 5. Total glaciated area and ice volume after $10 \mathrm{kyr}$ as a function of temperature offset for each climate forcing used.
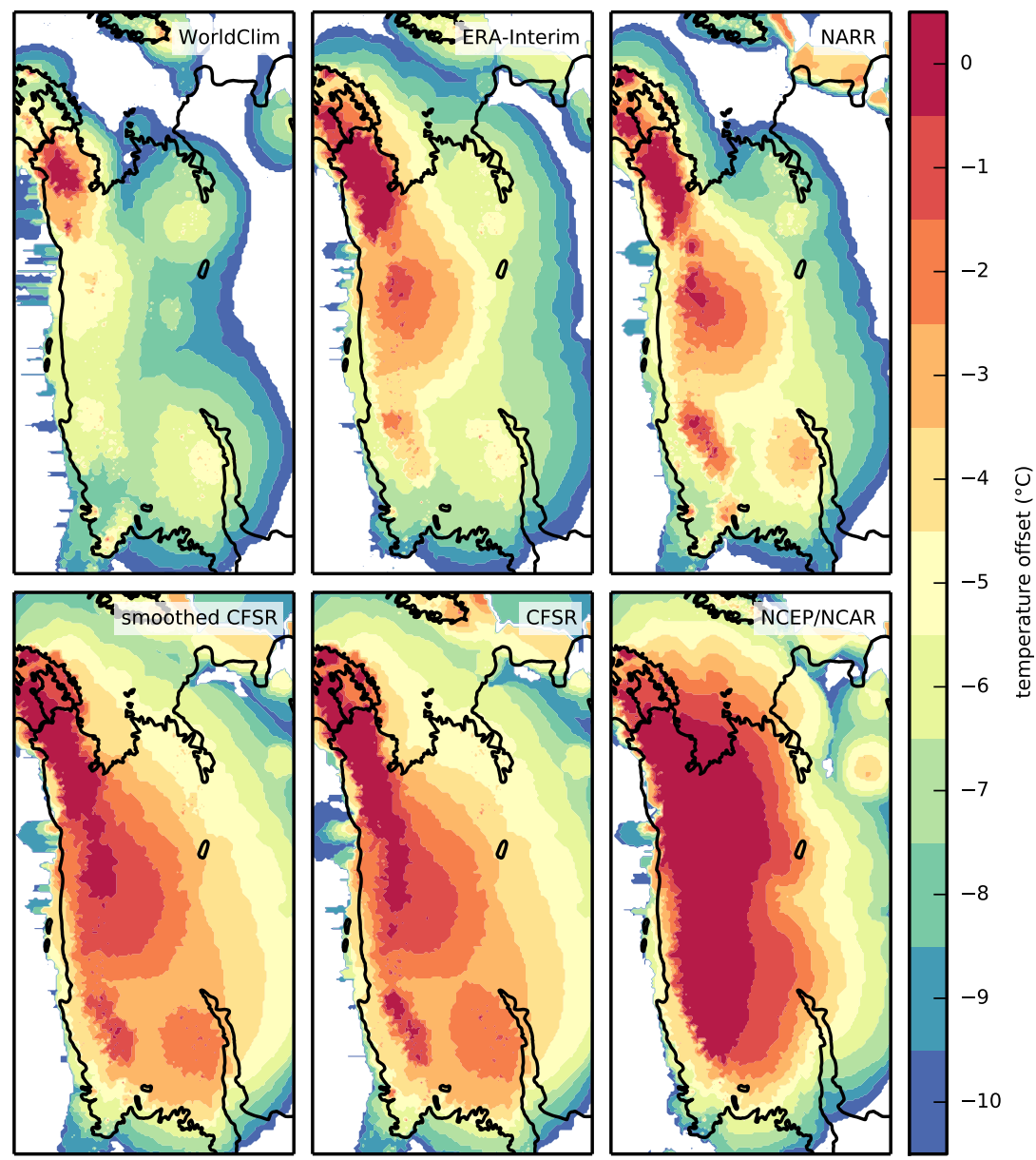

Figure 6. Extent of ice cover after $10 \mathrm{kyr}$ as a function of applied temperature offsets for each climate forcing used. A reconstructed LGM ice sheet margin by Dyke (2004) (Fig. 1) is given for reference (black line).

a reference with which to compare other climate forcing data on land.

Because much of the disparity between reanalyses and observational temperature data is caused by topographical detail at scales unresolved in the reanalyses, we apply a lapse- rate correction prior to this comparison, using the same lapse rate of $6^{\circ} \mathrm{C} \mathrm{km}^{-1}$ as in the simulations. ERA-Interim, CFSR and NARR climatologies exhibit temperature distributions fairly consistent with WorldClim data (Fig. 8). The spatial distribution of temperature differences between reanalyses 

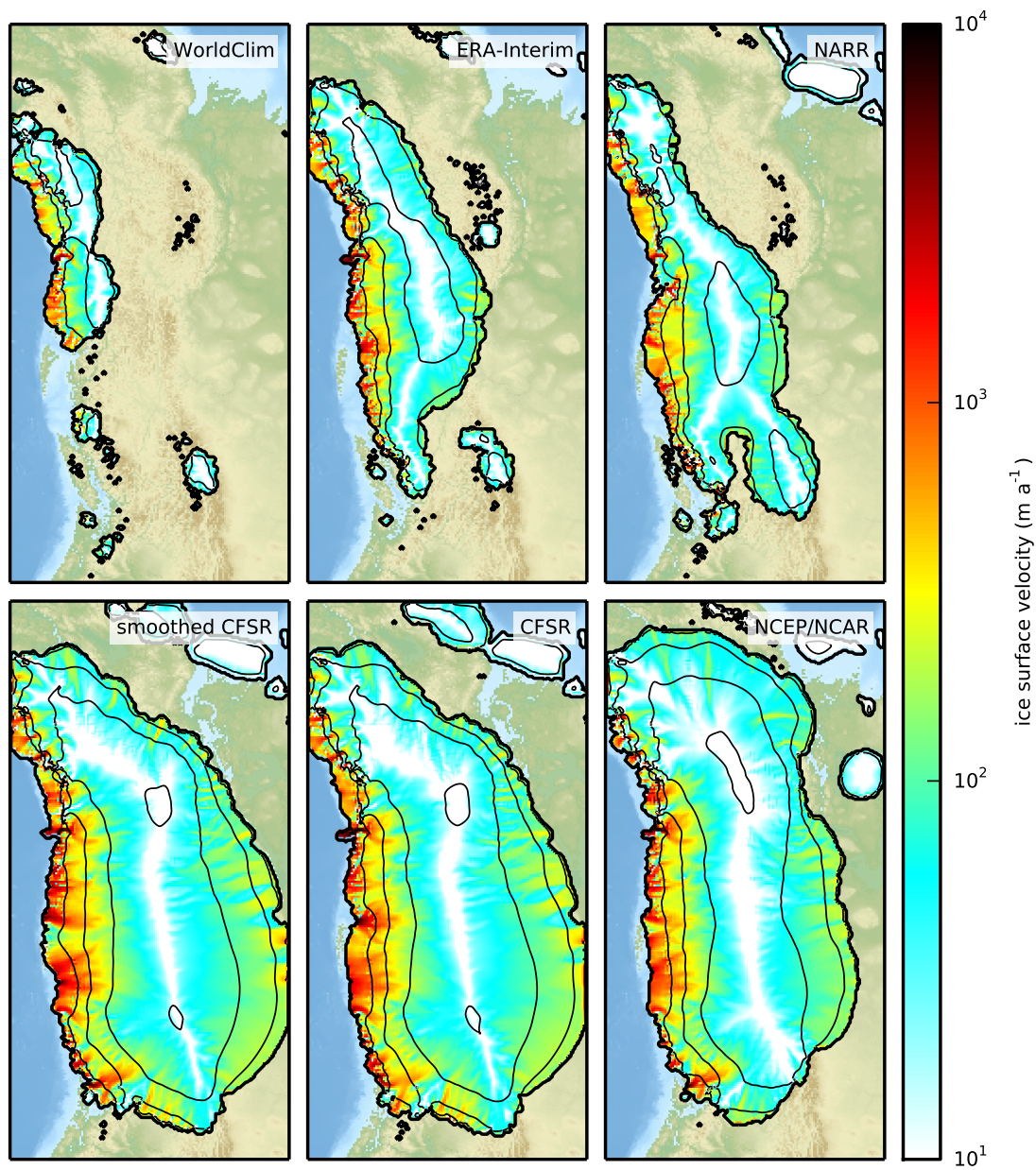

Figure 7. Ice surface topography $\left(1 \mathrm{~km}\right.$ contours) and velocity $\left(\mathrm{m} \mathrm{yr}^{-1}\right)$ after $10 \mathrm{kyr}$ under a climate $5{ }^{\circ} \mathrm{C}$ colder than present for each climate forcing used.

and WorldClim data shows partly consistent patterns, such as positive anomalies in the northernmost part of the modelling domain. These may relate to weaknesses of WorldClim data in areas of sparse observational coverage (Fig. 9). However, significant disparity among reanalyses exists, too. More specifically, surface air temperature data from the NCEP/NCAR climatology shows the largest disparity with that of WorldClim, with a significant cold anomaly over most of the modelling domain (Figs. 8 and 9).

All four reanalyses used in this study exhibit higher precipitation rates than WorldClim data (Fig. 10). However the magnitude of this anomaly differs significantly between data sets. The spatial distributions of precipitation differences between reanalyses and WorldClim data show that negative precipitation anomalies are generally constrained to the windward slope of the major mountain ranges, while positive precipitation anomalies are found on the leeward slope of these ranges and extend downwind to interior plateaux and lowlands (Fig. 11).
Most likely, this is the signature of an orographic precipitation effect. The topography of the Northern American Cordillera is such that its western ranges form a continuous orographic barrier, causing high precipitation along the $\mathrm{Pa}-$ cific coast while leaving much of the interior arid. The ability of a GCM to reproduce these contrasts in precipitation is bounded by spatial resolution. In a model of coarser resolution, these high mountain ranges are reduced to smooth hills and the modelled distribution of precipitation is also smoother (Fig. 12). However, this effect alone cannot explain the widespread and pronounced positive precipitation anomalies observed in CFSR data (Figs. 10 and 11) despite its high-spatial resolution (Table 1).

\subsection{Model sensitivity to climate forcing}

To distinguish the effects of temperature and precipitation biases on the ice sheet model, we run a series of eight additional simulations. These new simulations use a "hybrid" climate forcing that consists of temperature data from WorldClim, combined with precipitation data from each of the four 


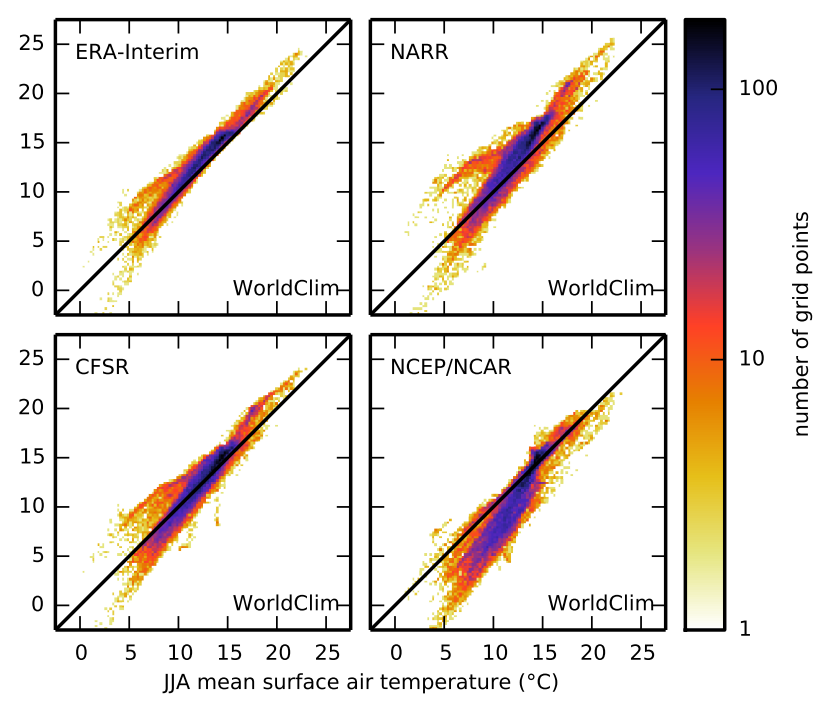

Figure 8. Density maps showing a comparison of summer (JJA) surface air temperature data from the WorldClim climatology, against that of each reanalysis. Climate data are presented after bilinear spatial interpolation and correction for topographic differences to WorldClim data, using a lapse rate of $6^{\circ} \mathrm{C} \mathrm{km}^{-1}$. Colour mapping is based on a logarithmic scale. Note the cold bias of NCEP/NCAR data relative to WorldClim data.

reanalyses, and vice-versa. A single temperature offset of $-5^{\circ} \mathrm{C}$ is used. This value was chosen to allow for comparison with previous results (Fig. 7). In each case, temperature lapse rates are computed using the reference topography from the corresponding data set.

Although only temperature or precipitation changes are applied, this experiment results once more in large differences in modelled ice sheet geometries (Fig. 13) as compared to the reference WorldClim $-5^{\circ} \mathrm{C}$ run (Fig. 7, top-left panel). For ERA-Interim, CFSR and NARR climatologies, precipitation anomalies clearly dominate the differences in ice sheet response, whereas temperature anomalies have relatively little effect (Fig. 14). However, in the case of NCAR forcing, both the negative temperature bias (Figs. 8 and 9) and the important precipitation differences (Figs. 10 and 11) contribute approximately equally to produce oversized ice sheets (Fig. 14).

\subsection{Comparison to geomorphological LGM margin reconstruction}

We compare modelled ice sheet geometries to a reconstruction of the ice margin at $14{ }^{14} \mathrm{C} \mathrm{kyr} \mathrm{BP}(16.8 \mathrm{cal} \mathrm{kyr} \mathrm{BP})$ by Dyke (2004), based on glacial geomorphology and radiocarbon dating (Fig. 1). This corresponds to the LGM extent of most of the Cordilleran ice sheet, which occurred later than for the Laurentide ice sheet (Porter and Swanson, 1998; Dyke, 2004; Stroeven et al., 2010, 2014).

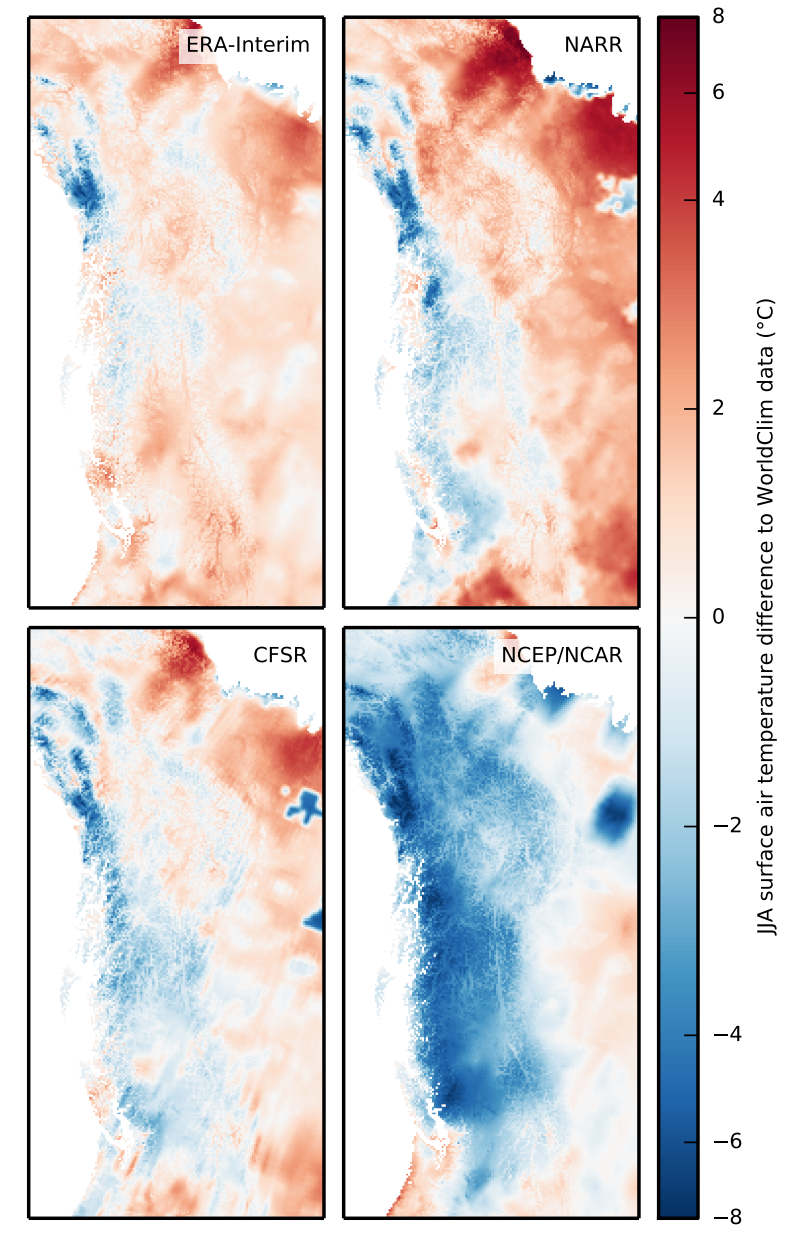

Figure 9. Summer (JJA) surface air temperature difference maps against WorldClim data, after bilinear spatial interpolation and lapse-rate correction. Note the cold bias of NCEP/NCAR data and temperature anomalies due to unresolved topographic detail.

Considering previously identified weaknesses of the CFSR and NCEP/NCAR data (Figs. 8-14), we restrict our analysis to the WorldClim, ERA-Interim and NARR input climatologies. In order to compare modelled ice sheets of a similar size, we select for each climate forcing the simulation that leads to a final glaciated area closest to the approximate size of the LGM Cordilleran ice sheet of $2 \times 10^{6} \mathrm{~km}^{2}$. This corresponds to temperature offset values of $-8^{\circ} \mathrm{C}$ (WorldClim), $-6^{\circ} \mathrm{C}$ (ERA-Interim) and $-7^{\circ} \mathrm{C}$ (NARR). These qualitative "best" runs are presented in Fig. 15 along with their associated temperature depressions and a reconstruction of the LGM ice sheet margin by Dyke (2004).

Although this selection results in similarly sized ice sheets, noticeable differences in shape exist. The ERA-Interim simulation produces a more northerly centred ice sheet with too much ice in the north and too little in the south. This may partly reflect unresolved orographic precipitation effects (Fig. 12) due to the coarser GCM resolution (Table 1). The 


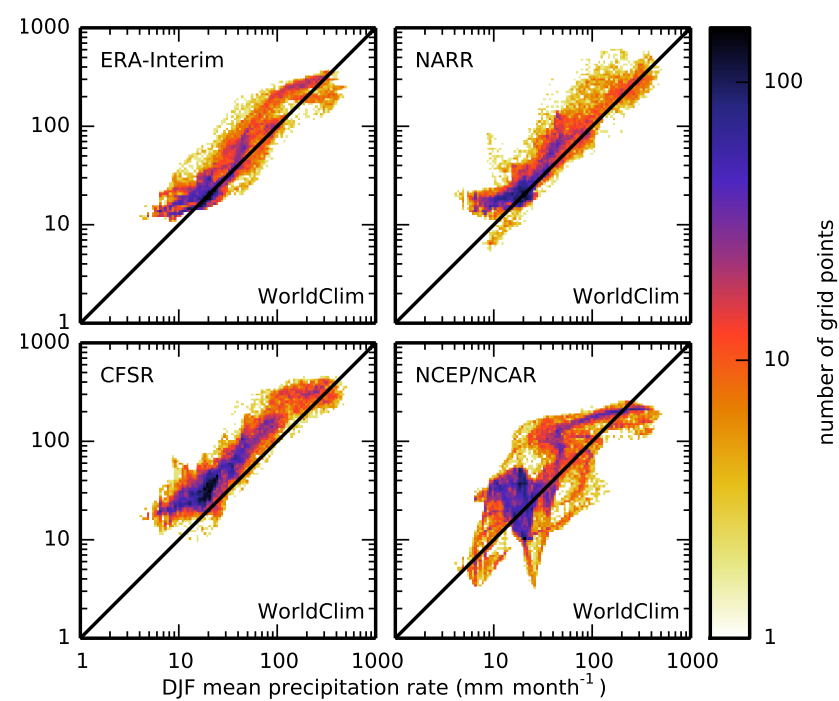

Figure 10. Density maps showing a comparison of winter (DJF) precipitation rate from the WorldClim climatology, against that of each reanalysis, after bilinear spatial interpolation. Colour mapping is based on a logarithmic scale. Note the wet bias of all reanalysis data relative to WorldClim data.

LGM ice sheet margin by Dyke (2004) is best reproduced by simulations driven by input climatologies from WorldClim and NARR data. However, common discrepancies between the modelled ice sheet geometry and the geomorphological reconstruction can still be observed (Fig. 15).

First, the modelled eastern margin of the ice sheet extends further east than the inferred position of the junction between the Cordilleran and the Laurentide ice sheets. This can be seen for instance in the south-eastern part of our modelling domain, where the modelled ice sheets cover an ice-free corridor of the LGM reconstruction (Fig. 15). However, such comparisons have been hampered by the fact that we have not considered the buttressing effect of the Laurentide ice sheet, which would have inhibited the Cordilleran ice sheet from advancing onto the Canadian Prairies. In addition, potential effects of the growing ice-sheet on atmospheric circulation and precipitation changes are not included in our model. The Cordilleran ice sheet initiated from the formation of mountain ice caps over the high mountain ranges (Clague, 1989). In our simulations, a continuous ice cover quickly forms over the western ranges, where precipitation rates are higher than in the rest of the domain. In reality, this continuous ice cover enhanced the topographical barrier already formed by the western ranges, and would have resulted in less precipitation and warmer air in the interior. This process of "self-inhibiting growth" is not captured in our model but was demonstrated to be important in a similar setting over Greenland, where it may have been limiting the advance of the ice sheet during its build-up (Langen et al., 2012).

Second, our simulations produce anomalous ice cover on parts of the continental shelf in the Arctic Ocean (Fig. 15).

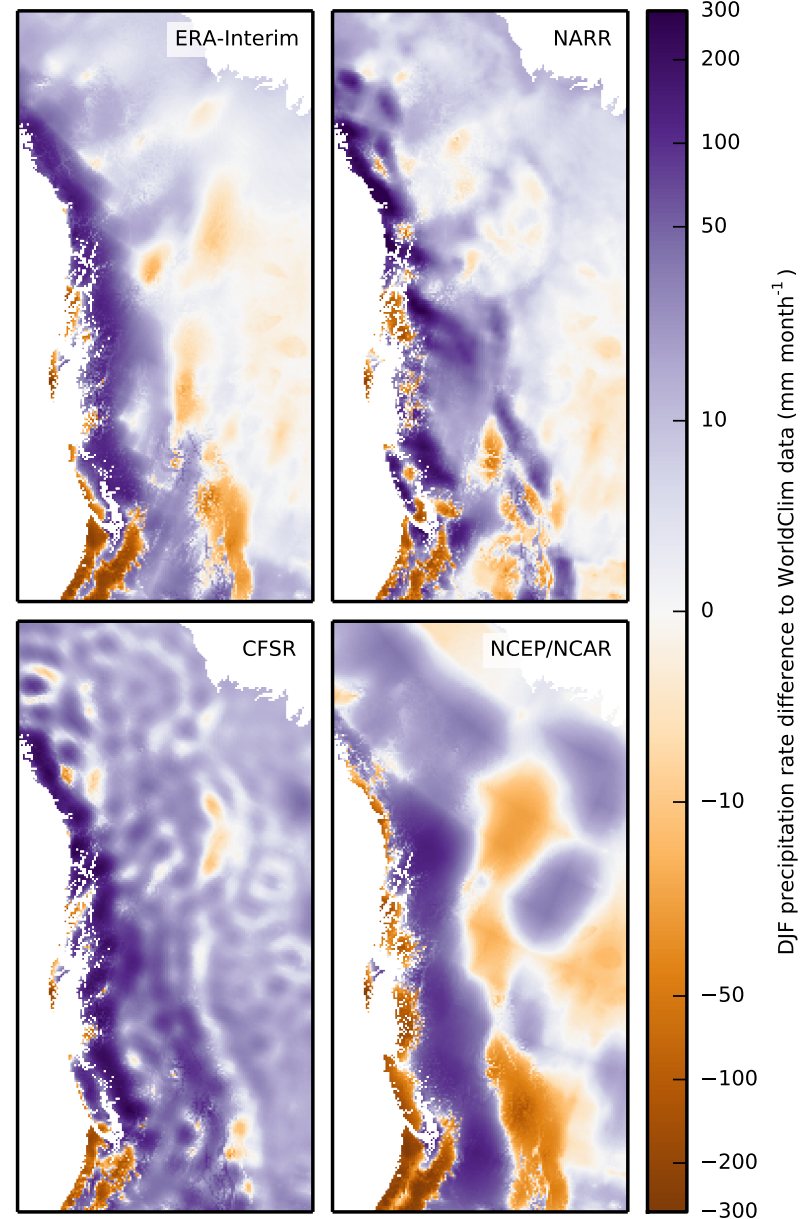

Figure 11. Winter (DJF) precipitation rate difference maps against WorldClim data, after bilinear spatial interpolation. Note the wet bias of all reanalysis data and the large anomalies of CFSR and NCEP/NCAR data.

These regions experience a marine climate, including lower summer temperature than on the adjacent land (Fig. 3). However in our simulations, sea level is lowered by $120 \mathrm{~m}$, turning large parts of the low-sloping continental shelf into land. This anomalous ice cover is to be interpreted as an artefact arising from our simplistic temperature offset method, and has little effect on the rest of the results.

Given the lack of WorldClim data offshore, we consider the NARR climate forcing as best suited for simulations of the Cordilleran ice sheet among those tested, and under the assumptions of the present study.

\subsection{Model sensitivity to the duration of ice sheet inception}

Most of the simulations presented in this study, and more particularly those that reproduce the LGM ice margin reconstruction more closely (Fig. 15) do not reach a steady state. Instead, rates of growth remain high throughout the run, and 


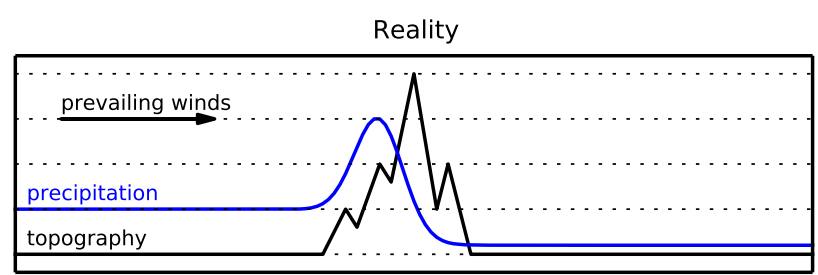

High resolution circulation model

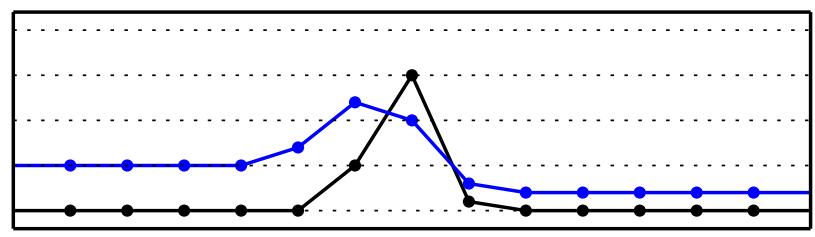

Low resolution circulation model

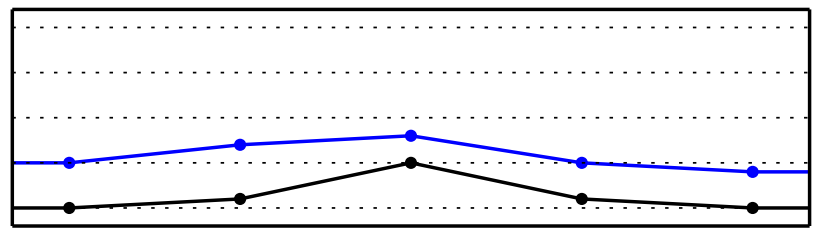

Figure 12. Schematic representation of the orographic precipitation effect over a mountain range. In a GCM of low resolution, the precipitation peak appears downwind shifted and smoother and the precipitation shadow is less pronounced than in a high-resolution GCM.

bed elevation does not come close to equilibrium with the ice load. In turn, a key assumption for the present study is our choice of $10 \mathrm{kyr}$ for the duration of all our simulations. Although geomorphological data shows that the period of Cordilleran ice sheet inception, from nearly ice free to full glacial conditions, could not have been much longer than $10 \mathrm{kyr}$, they provide no lower bound to this value.

To test the effect of an inception period of shorter duration on model results, we use simulations run under NARR climate forcing with temperature offsets of -11 to $-7^{\circ} \mathrm{C}$, and compare modelled ice sheet extent when glaciated area reaches the approximate size of the LGM Cordilleran ice sheet of $2 \times 10^{6} \mathrm{~km}^{2}$.

This experiment shows that a shorter start-up period leads to more restricted ice cover in the eastern part of the modelling domain, where precipitation rate controls ice advance, but more extensive glaciation in the south-western domain along the Pacific coast, where temperature is the limiting factor (Fig. 16). Hence, reducing simulation duration leads to a closer match with the LGM ice sheet margin by Dyke (2004) in some sectors of the modelling domain, but higher discrepancy in other sectors.

\subsection{Other potential method improvements}

Our representation of climate history by constant temperature offsets is voluntarily simplistic. To better understand the transient character of the LGM Cordilleran ice sheet, time-dependent palaeo-climate forcing would be needed. Although it is clear that past temperature changes over the region were neither homogeneous nor constant in time, their patterns are not trivial and may potentially display a strong inter-dependence with the evolution of the Cordilleran and Laurentide ice sheets. As previously discussed, potential effects of the growing ice sheet on precipitation changes are not included in our model. These changes likely consisted of a reduction of precipitation in continental regions and in the ice sheet interior, and an increase of precipitation along part of the margin where the presence of ice imposed ascending winds. They could have resulted in a more westerly centred ice sheet than modelled here, with lower ice thickness in its interior. In addition, the final position of the eastern ice margin is largely controlled by its advance rate through the run. Therefore, the precipitation shadowing effects may have resulted in more similar ice-sheet configurations if they were included in the model. Although using a GCM of intermediate complexity (Yoshimori et al., 2001; Calov et al., 2002; Abe-Ouchi et al., 2007; Charbit et al., 2013) may represent a first step towards including ice sheet feedback on climate, their spatial resolution does not allow for accurate modelling of orographic precipitation changes in a region as mountainous as the North American Cordillera.

Furthermore, the surface mass balance model crudely simplifies the processes taking place at the glacier surface. Refreezing of melted snow and ice and water retention in the snow pack was shown to influence surface mass balance of glaciers (Trabant and Mayo, 1985), yet it is not accounted for in our PDD model. Based on scarce observations over the Greenland Ice Sheet, different parametrisations of this effect have been developed (Janssens and Huybrechts, 2000; Fausto et al., 2009b). However, these parametrisations were shown to disagree with more complex models (Reijmer et al., 2012), and it remains undemonstrated whether their application to a different region and time period is sound. In addition, we simulate temperature variability by using a constant, uniform value of daily temperature standard deviation. This approach implies large biases in surface mass balance (Charbit et al., 2013; Rogozhina and Rau, 2014; Seguinot, 2013), particularly over regions with such various climates as experienced within our model domain.

The bedrock deformation model uses homogeneous lithospheric properties and a semi-infinite mantle of constant viscosity. Thus, it does not represent lateral variations of crustal and mantle properties characteristic of tectonically active margins such as the American Cordillera, nor does it include the influence from the neighbouring Laurentide ice sheet. These limitations should be acknowledged when interpreting ice surface elevation and volume reconstructions presented in this study. 

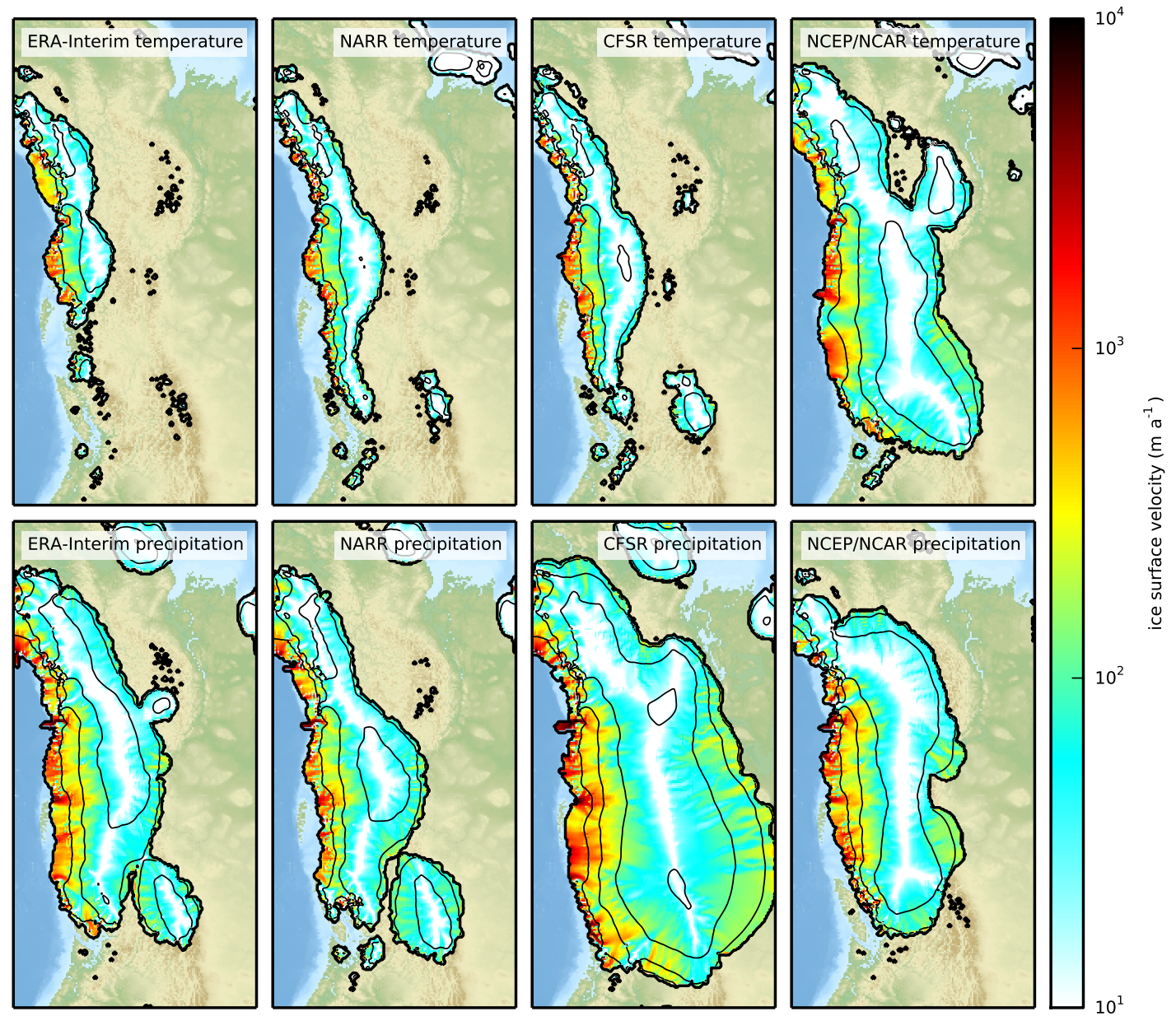

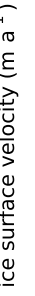

Figure 13. Ice surface topography ( $1 \mathrm{~km}$ contours) and velocity $\left(\mathrm{m} \mathrm{yr}^{-1}\right)$ after $10 \mathrm{kyr}$ using "hybrid" climate forcing with precipitation rate from WorldClim and surface air temperature from each reanalysis (upper row), and surface air temperature from WorldClim and precipitation rate from each reanalysis (lower row). In other words, the upper row shows the effect of temperature anomalies, and the lower row the effect of precipitation anomalies, for each reanalysis, relative to WorldClim data. Each simulation uses a $-5^{\circ} \mathrm{C}$ offset for comparison with Fig. 7 .

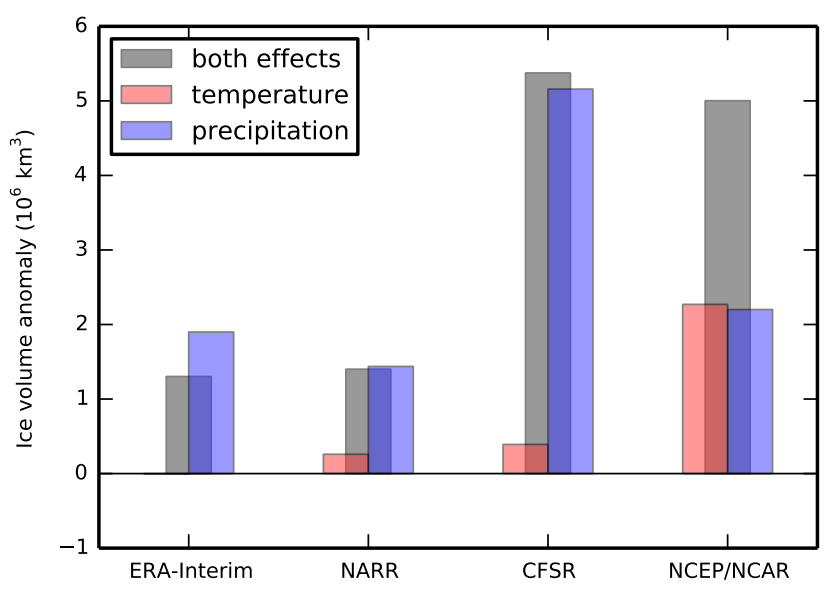

Figure 14. Effect of temperature and precipitation anomalies (separately and jointly) from each reanalysis on modelled final ice volume relative to the result of the WorldClim $-5^{\circ} \mathrm{C}$ offset simulation. Corresponding ice sheet geometries are presented in Figs. 7 and 13.

\section{Conclusions}

Our study shows a strong dependency of ice sheet model results on the choice of climate forcing data. For three of the four reanalysis data sets used, precipitation rate, over surface air temperature, causes much of the variation in modelled ice sheet outlines and volumes. Furthermore, the spatial resolution of input data appears critical for providing the ice sheet model with an accurate precipitation field, confirming the results obtained by Quiquet et al. (2012) from various GCM forcing data sets over the Greenland Ice Sheet.

For the Cordilleran ice sheet, we achieve the best fit to the mapped LGM margin by Dyke (2004) using climate forcing from the high-resolution interpolated observational data set WorldClim (Hijmans et al., 2005) and the North American Regional Reanalysis (NARR; Mesinger et al., 2006). The latter data set is preferable in our case due to the lack of WorldClim data offshore. Climate forcing from CFSR and the NCEP/NCAR reanalysis produce largely oversized ice 

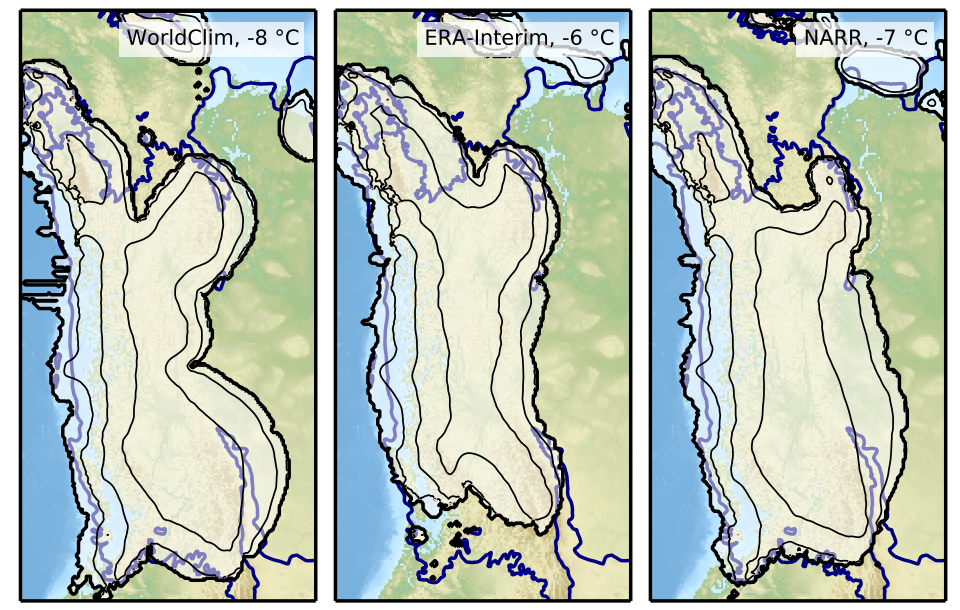

Figure 15. Ice surface topography ( $1 \mathrm{~km}$ contours) after $10 \mathrm{kyr}$ using temperature offsets resulting in glaciated areas of circa $2 \times 10^{6} \mathrm{~km}^{2}$. A reconstructed LGM ice sheet margin by Dyke (2004) (Fig. 1) is given for reference (blue line).
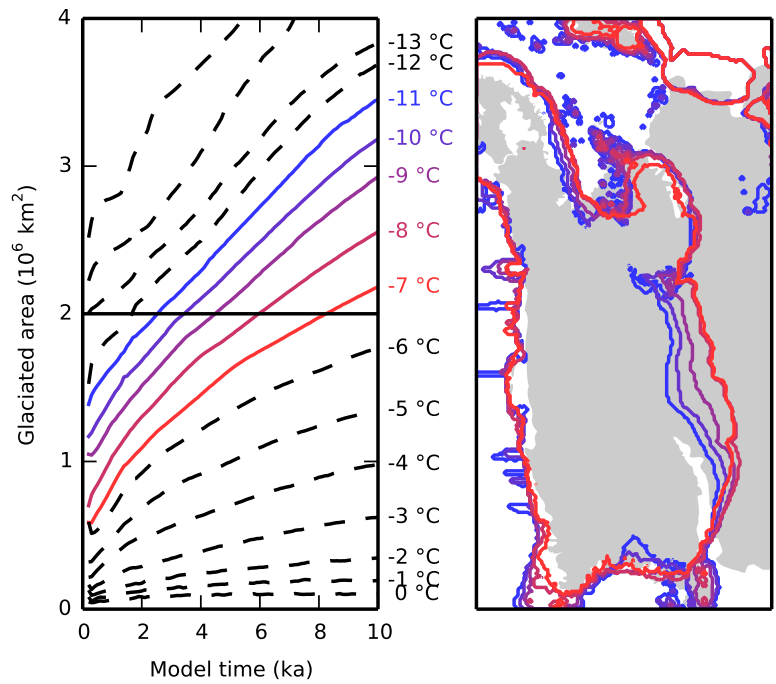

Figure 16. Left panel: model sensitivity to simulation length. Modelled glaciated area, using NARR forcing data, and temperature offsets from -15 to $0^{\circ} \mathrm{C}$, solid lines corresponding to values from -11 to $-7^{\circ} \mathrm{C}$. Right panel: modelled ice margin corresponding to temperature offsets from -11 to $-7^{\circ} \mathrm{C}$ when total glaciated area reaches the approximate size of the LGM Cordilleran ice sheet of $2 \times 10^{6} \mathrm{~km}^{2}$. A reconstructed LGM ice sheet margin by Dyke (2004) (Fig. 1) is given for reference (grey shading). Note that shorter (and colder) simulations lead to more restrictive glaciation of the continental eastern margin but further ice extent in the maritime southwestern part of the modelling domain.

sheets due to too high precipitation rates, and in the second case, too low surface air temperature. The ERA-Interim data used in this study produces more reasonable results, but it may be too coarse to accurately resolve the spatial distribution of orographic precipitation associated with the rugged topography of the study area, resulting in misplaced ice cov- erage in regard to geomorphological data. Therefore, we retain NARR data for forcing simulations of the Cordilleran ice sheet in the future.

One must keep in mind, however, that these results are only accurate for our choices of ice-sheet model (PISM), surface mass balance model (PDD), study object (the Cordilleran ice sheet), and, most importantly, palaeo-climate representation (temperature offsets). At LGM, it is most likely that the presence of ice sheets significantly affected circulation patterns and distribution of precipitation. At the cost of greater computational expense, a more accurate representation of palaeo-climate may allow for a better fit between model results and the mapped LGM margin.

\section{Author contributions}

J. Seguinot ran the simulations and wrote most of the paper; C. Khroulev implemented necessary code changes in PISM; I. Rogozhina helped with model set-up and experiment design; A. P. Stroeven initiated the Cordilleran ice sheet modelling project; and Q. Zhang prepared some of the forcing data. All authors contributed to the paper.

Acknowledgements. We thank Ed Bueler and Andy Aschwanden for providing constant support on PISM and patiently answering our questions on the code internals, Laurent Brodeau and Soon-Heum Ko for assistance concerning software installations on supercomputing resources, two anonymous referees for supporting publication of this work, Frank Pattyn for constructive editorial comments prior to publication of the discussion paper, and all PISM authors for providing the model open source. This work was supported by the Swedish Research Council (VR) grant no. 2008-3449 to A. P. Stroeven, by the German Academic Exchange Service (DAAD) grant no. 50015537, the Knut and Alice Wallenberg Foundation, and the Carl Mannerfelt fund to J. Seguinot, 
and by NASA grant no. NNX13AM16G to E. Bueler. Computer resources were provided by the Swedish National Infrastructure for Computing (SNIC) allocation no. 2013/1-145 to A. P. Stroeven at the National Supercomputing Center (NSC).

Edited by: F. Pattyn

\section{References}

Abe-Ouchi, A., Segawa, T., and Saito, F.: Climatic Conditions for modelling the Northern Hemisphere ice sheets throughout the ice age cycle, Clim. Past, 3, 423-438, doi:10.5194/cp-3-423-2007, 2007.

Amante, C. and Eakins, B. W.: ETOPO1 1 arc-minute global relief model: procedures, data sources and analysis, NOAA technical memorandum NESDIS NGDC-24, 2009.

Artemieva, I. M. and Mooney, W. D.: Thermal thickness and evolution of Precambrian lithosphere: a global study, J. Geophys. Res., 106, 16387-16414, doi:10.1029/2000JB900439, 2001.

Aschwanden, A. and Blatter, H.: Mathematical modeling and numerical simulation of polythermal glaciers, J. Geophys. Res., 114, F01027, doi:10.1029/2008JF001028, 2009.

Aschwanden, A., Bueler, E., Khroulev, C., and Blatter, H.: An enthalpy formulation for glaciers and ice sheets, J. Glaciol., 58, 441-457, doi:10.3189/2012JoG11J088, 2012.

Aschwanden, A., Aðalgeirsdóttir, G., and Khroulev, C.: Hindcasting to measure ice sheet model sensitivity to initial states, The Cryosphere, 7, 1083-1093, doi:10.5194/tc-7-1083-2013, 2013.

Bengtsson, L., Haines, K., Hodges, K. I., Arkin, P., Berrisford, P., Bougeault, P., Kallberg, P., Simmons, A. J., Uppala, S., Folland, C. K., Gordon, C., Rayner, N., Thorne, P. W., Jones, P., Stammer, D., and Vose, R. S.: The need for a dynamical climate reanalysis, B. Am. Meteorol. Soc., 88, 495-501, doi:10.1175/BAMS-88-4-495, 2007.

Bintanja, R., van de Wal, R. S. W., and Oerlemans, J.: A new method to estimate ice age temperatures, Clim. Dynam., 24, 197-211, doi:10.1007/s00382-004-0486-x, 2005.

Blackwell, D. D. and Richards, M.: Geothermal Map of North America, American Association of Petroleum Geologists (AAPG), 1 sheet, scale $1: 6500000,2004$.

Bueler, E. and Brown, J.: Shallow shelf approximation as a "sliding law" in a thermodynamically coupled ice sheet model, J. Geophys. Res., 114, F03008, doi:10.1029/2008JF001179, 2009.

Bueler, E. and Lingle, C. S. and Brown, J.: Fast computation of a viscoelastic deformable Earth model for ice-sheet simulations, Ann. Glaciol., 46, 97-105, doi:10.3189/172756407782871567, 2007

Calov, R. and Greve, R.: A semi-analytical solution for the positive degree-day model with stochastic temperature variations, J. Glaciol., 51, 173-175, doi:10.3189/172756505781829601, 2005.

Calov, R., Ganopolski, A., Petoukhov, V., Claussen, M., and Greve, R.: Large-scale instabilities of the Laurentide ice sheet simulated in a fully coupled climate-system model, Geophys. Res. Lett., 29, 2216, doi:10.1029/2002GL016078, 2002.

Charbit, S., Ritz, C., and Ramstein, G.: Simulations of Northern Hemisphere ice-sheet retreat: sensitivity to physical mechanisms involved during the Last Deglaciation, Quaternary Sci. Rev., 21, 243-265, doi:10.1016/S0277-3791(01)00093-2, 2002.
Charbit, S., Ritz, C., Philippon, G., Peyaud, V., and Kageyama, M.: Numerical reconstructions of the Northern Hemisphere ice sheets through the last glacial-interglacial cycle, Clim. Past, 3, 15-37, doi:10.5194/cp-3-15-2007, 2007.

Charbit, S., Dumas, C., Kageyama, M., Roche, D. M., and Ritz, C.: Influence of ablation-related processes in the build-up of simulated Northern Hemisphere ice sheets during the last glacial cycle, The Cryosphere, 7, 681-698, doi:10.5194/tc-7-681-2013, 2013.

Clague, J. J.: Quaternary geology of the Canadian Cordillera, in: Quaternary Geology of Canada and Greenland, edited by: Fulton, R. J., Geological Society of America, Boulder, CO, 15-95, 1989.

Dee, D. P., Uppala, S. M., Simmons, A. J., Berrisford, P., Poli, P., Kobayashi, S., Andrae, U., Balmaseda, M. A., Balsamo, G., Bauer, P., Bechtold, P., Beljaars, A. C. M., van de Berg, L., Bidlot, J., Bormann, N., Delsol, C., Dragani, R., Fuentes, M., Geer, A. J., Haimberger, L., Healy, S. B., Hersbach, H., Hólm, E. V., Isaksen, L., Kållberg, P., Köhler, M., Matricardi, M., McNally, A. P., Monge-Sanz, B. M., Morcrette, J.-J., Park, B.K., Peubey, C., de Rosnay, P., Tavolato, C., Thépaut, J.-N., and Vitart, F.: The ERA-Interim reanalysis: configuration and performance of the data assimilation system, Q. J. Roy. Meteor. Soc., 137, 553-597, doi:10.1002/qj.828, 2011.

Duk-Rodkin, A.: Glacial limits map of Yukon Territory, Geol. Surv. of Can., Ottawa, Ont., Open File 3694, doi:10.4095/210739, 1999.

Dyke, A. S.: An outline of North American deglaciation with emphasis on central and northern Canada, in: Quaternary Glaciations - Extent and Chronology, Part II, edited by: Ehlers, J. and Gibbard, P. L., Elsevier, 373-424, doi:10.1016/S15710866(04)80209-4, 2004.

Fausto, R. S., Ahlstrøm, A. P., Van As, D., Bøggild, C. E., and Johnsen, S. J.: A new present-day temperature parameterization for Greenland, J. Glaciol., 55, 95-105, doi:10.3189/002214309788608985, 2009a.

Fausto, R. S., Ahlstrøm, A. P., Van As, D., Johnsen, S. J., Langen, P. L., and Steffen, K.: Improving surface boundary conditions with focus on coupling snow densification and meltwater retention in large-scale ice-sheet models of Greenland, J. Glaciol., 55, 869-878, doi:10.3189/002214309790152537, 2009b.

Gesch, D. B., Verdin, K. L., and Greenlee, S. K.: New land surface digital elevation model covers the Earth, Eos, Transactions American Geophysical Union, 80, 69-70, doi:10.1029/99EO00050, 1999.

Gregoire, L. J., Payne, A. J., and Valdes, P. J.: Deglacial rapid sea level rises caused by ice-sheet saddle collapses, Nature, 487, 219-222, doi:10.1038/nature11257, 2012.

Greve, R., Wyrwoll, K.-H., and Eisenhauer, A.: Deglaciation of the Northern Hemisphere at the onset of the Eemian and Holocene, Ann. Glaciol., 28, 1-8, doi:10.3189/172756499781821643, 1999.

Hebeler, F., Purves, R. S., and Jamieson, S. S.: The impact of parametric uncertainty and topographic error in ice-sheet modelling, J. Glaciol., 54, 899-919, doi:10.3189/002214308787779852, 2008.

Hijmans, R. J., Cameron, S. E., Parra, J. L., Jones, P. G., and Jarvis, A.: Very high resolution interpolated climate sur- 
faces for global land areas, Int. J. Climatol., 25, 1965-1978, doi:10.1002/joc.1276, 2005.

Hock, R.: Temperature index melt modelling in mountain areas, J. Hydrol., 282, 104-115, doi:10.1016/S0022-1694(03)00257-9, 2003.

Hunter, J. D.: Matplotlib: a 2-D graphics environment, Comput. Sci. Eng., 9, 90-95, doi:10.1109/MCSE.2007.55, 2007.

Huybrechts, P. and T'siobbel, S.: A three-dimensional climate-icesheet model applied to the Last Glacial Maximum, Ann. Glaciol., 25, 333-339, doi:10013/epic.12066, 1996.

Jackson, L. E. and Clague, J. J.: The Cordilleran ice sheet: one hundred and fifty years of exploration and discovery, Géogr. phys. Quatern., 45, 269-280, doi:10.7202/032874ar, 1991.

Janssens, I. and Huybrechts, P.: The treatment of meltwater retention in mass-balance parameterizations of the Greenland ice sheet, Ann. Glaciol., 31, 133-140, doi:10.3189/172756400781819941, 2000.

Jarvis, A., Reuter, H., Nelson, A., and Guevara, E.: Hole-filled Seamless SRTM Data V4. International Centre for Tropical Agriculture, available at: http://srtm.csi.cgiar.org, 2005.

Johnson, J. and Fastook, J. L.: Northern Hemisphere glaciation and its sensitivity to basal melt water, Quaternary Int., 95-96, 65-74, doi:10.1016/S1040-6182(02)00028-9, 2002.

Joussaume, S. and Taylor, K.: Status of the Paleoclimate Modeling Intercomparison Project (PMIP), in: First International AMIP Conference, Proceedings of the first international AMIP Conference, edited by: Gates, W. L., World. Meteorol. Organ., Geneva, 425-430, 1995.

Kalnay, E., Kanamitsu, M., Kistler, R., Collins, W., Deaven, D., Gandin, L., Iredell, M., Saha, S., White, G., Woollen, J., Zhu, Y., Leetmaa, A., Reynolds, R., Chelliah, M., Ebisuzaki, W., Higgins, W., Janowiak, J., Mo, K. C., Ropelewski, C., Wang, J., Jenne, R., and Joseph, D.: The NCEP/NCAR 40-year reanalysis project, B. Am. Meteorol. Soc., 77, 437-471, doi:10.1175/15200477(1996)077<0437:TNYRP>2.0.CO;2, 1996.

Kaufman, D. S. and Manley, W. F.: Pleistocene Maximum and Late Wisconsinan glacier extents across Alaska, USA, in: Quaternary Glaciations - Extent and Chronology, Part II, edited by: Ehlers, J. and Gibbard, P. L., Elsevier, 9-27, doi:10.1016/S15710866(04)80182-9, 2004.

Kleman, J., Jansson, K., De Angelis, H., Stroeven, A., Hättestrand, C., Alm, G., and Glasser, N.: North American ice sheet build-up during the last glacial cycle, 115-21 kyr, Quaternary Sci. Rev., 29, 2036-2051, doi:10.1016/j.quascirev.2010.04.021, 2010.

Langen, P. L., Solgaard, A. M., and Hvidberg, C. S.: Self-inhibiting growth of the Greenland ice sheet, Geophys. Res. Lett., 39, L12502, doi:10.1029/2012GL051810, 2012.

Lingle, C. S. and Clark, J. A.: A numerical model of interactions between a marine ice sheet and the solid Earth: application to a West Antarctic ice stream, J. Geophys. Res., 90, 1100-1114, doi:10.1029/JC090iC01p01100, 1985.

Margold, M., Jansson, K. N., Kleman, J., and Stroeven, A. P.: Glacial meltwater landforms of central British Columbia, J. Maps, 7, 486-506, doi:10.4113/jom.2011.1205, 2011.

Marshall, S. J. and Clarke, G. K. C.: Modeling North American freshwater runoff through the Last Glacial Cycle, Quaternary Res., 52, 300-315, doi:10.1006/qres.1999.2079, 1999.
Martin, M. A., Winkelmann, R., Haseloff, M., Albrecht, T., Bueler, E., Khroulev, C., and Levermann, A.: The Potsdam Parallel Ice Sheet Model (PISM-PIK) - Part 2: Dynamic equilibrium simulation of the Antarctic ice sheet, The Cryosphere, 5, 727740, doi:10.5194/tc-5-727-2011, 2011.

Mesinger, F., DiMego, G., Kalnay, E., Mitchell, K., Shafran, P. C., Ebisuzaki, W., Jović, D., Woollen, J., Rogers, E., Berbery, E. H., Ek, M. B., Fan, Y., Grumbine, R., Higgins, W., Li, H., Lin, Y., Manikin, G., Parrish, D., and Shi, W.: North American regional reanalysis, B. Am. Meteorol. Soc., 87, 343-360, doi:10.1175/BAMS-87-3-343, 2006.

Neteler, M., Bowman, M., Landa, M., and Metz, M.: GRASS GIS: a multi-purpose Open Source GIS, Environ. Modell. Softw., 31, 124-130, doi:10.1016/j.envsoft.2011.11.014, 2011.

NOAA/OAR/ESRL Physical Sciences Division: http://www.esrl. noaa.gov/psd/, 2013.

Oliphant, T. E.: Python for Scientific Computing, Comput. Sci. Eng., 9, 10-20, doi:10.1109/MCSE.2007.58, 2007.

Patterson, T. and Kelso, N. V.: Natural Earth. Free vector and raster map data, http://naturalearthdata.com, 2010.

Pattyn, F.: Antarctic subglacial conditions inferred from a hybrid ice sheet/ice stream model, Earth Planet. Sc. Lett., 295, 451-461, doi:10.1016/j.eps1.2010.04.025, 2010.

Peltier, W. R.: Ice Age paleotopography, Sience, 265, 195-201, doi:10.1126/science.265.5169.195, 1994.

Porter, S. C. and Swanson, T. W.: Radiocarbon age constraints on rates of advance and retreat of the Puget Lobe of the Cordilleran Ice Sheet during the last glaciation, Quaternary Res., 50, 205213, doi:10.1006/qres.1998.2004, 1998.

Quiquet, A., Punge, H. J., Ritz, C., Fettweis, X., Gallée, H., Kageyama, M., Krinner, G., Salas y Mélia, D., and Sjolte, J.: Sensitivity of a Greenland ice sheet model to atmospheric forcing fields, The Cryosphere, 6, 999-1018, doi:10.5194/tc-6-9992012, 2012.

Reijmer, C. H., van den Broeke, M. R., Fettweis, X., Ettema, J., and Stap, L. B.: Refreezing on the Greenland ice sheet: a comparison of parameterizations, The Cryosphere, 6, 743-762, doi:10.5194/tc-6-743-2012, 2012.

Robert, B. L.: Modeling the Cordilleran ice sheet, Géogr. Phys. Quatern., 45, 287-299, doi:10.7202/032876ar, 1991.

Rodgers, K. B., Charbit, S., Kageyama, M., Philippon, G., Ramstein, G., Ritz, C., Yin, J., Lohmann, G., Lorenz, S. J., and Khodri, M.: Sensitivity of Northern Hemispheric continental ice sheets to tropical SST during deglaciation, Geophys. Res. Lett., 31, L02206, doi:10.1029/2003GL018375, 2004.

Rogozhina, I. and Rau, D.: Vital role of daily temperature variability in surface mass balance parameterizations of the Greenland Ice Sheet, The Cryosphere, 8, 575-585, doi:10.5194/tc-8-575-2014, 2014.

Rogozhina, I., Hagedoorn, J. M., Martinec, Z., Fleming, K., Soucek, O., Greve, R., and Thomas, M.: Effects of uncertainties in the geothermal heat flux distribution on the Greenland ice sheet: an assessment of existing heat flow models, J. Geophys. Res., 117, F02025, doi:10.1029/2011JF002098, 2012.

Saha, S., Moorthi, S., Pan, H.-L., Wu, X., Wang, J., Nadiga, S., Tripp, P., Kistler, R., Woollen, J., Behringer, D., Liu, H., Stokes, D., Grumbine, R., Gayno, G., Wang, J., Hou, Y.-T., Chuang, H.-Y., Juang, H.-M. H., Sela, J., Iredell, M., Treadon, R., Kleist, D., Delst, P. V., Keyser, D., Derber, J., Ek, M., 
Meng, J., Wei, H., Yang, R., Lord, S., van den Dool, H., Kumar, A., Wang, W., Long, C., Chelliah, M., Xue, Y., Huang, B., Schemm, J.-K., Ebisuzaki, W., Lin, R., Xie, P., Chen, M., Zhou, S., Higgins, W., Zou, C.-Z., Liu, Q., Chen, Y., Han, Y., Cucurull, L., Reynolds, R. W., Rutledge, G., and Goldberg, M.: The NCEP climate forecast system reanalysis, B. Am. Meteorol. Soc., 91, 1015-1057, doi:10.1175/2010BAMS3001.1, 2010.

Seguinot, J.: Spatial and seasonal effects of temperature variability in a positive degree day surface melt model, J. Glaciol., 59, 1202-1204, doi:10.3189/2013JoG13J081, 2013.

Shea, J. M., Moore, R. D., and Stahl, K.: Derivation of melt factors from glacier mass-balance records in western Canada, J. Glaciol., 55, 123-130, doi:10.3189/002214309788608886, 2009.

Stroeven, A. P., Fabel, D., Codilean, A. T., Kleman, J., Clague, J. J., Miguens-Rodriguez, M., and Xu, S.: Investigating the glacial history of the northern sector of the Cordilleran ice sheet with cosmogenic ${ }^{10} \mathrm{Be}$ concentrations in quartz, Quaternary Sci. Rev., 29, 3630-3643, doi:10.1016/j.quascirev.2010.07.010, 2010.

Stroeven, A. P., Fabel, D., Margold, M., Clague, J. J., and Xu, S.: Investigating absolute chronologies of glacial advances in the NW sector of the Cordilleran ice sheet with terrestrial in situ cosmogenic nuclides, Quaternary Sci. Rev., 92, 429-443, doi:10.1016/j.quascirev.2013.09.026, 2014.

Tarasov, L. and Peltier, W. R.: Terminating the $100 \mathrm{kyr}$ ice age cycle, J. Geophys. Res., 102, 21665-21693, doi:10.1029/97JD01766, 1997.
Tarasov, L. and Peltier, W. R.: A geophysically constrained large ensemble analysis of the deglacial history of the North American ice-sheet complex, Quaternary Sci. Rev., 23, 359-388, doi:10.1016/j.quascirev.2003.08.004, 2004.

the PISM authors: PISM, a Parallel Ice Sheet Model, available at: http://www.pism-docs.org, 2013.

Trabant, D. C. and Mayo, L. R.: Estimation and effects of internal accumulation on five glaciers in Alaska, Ann. Glaciol., 6, 113117,1985

Whitaker, J.: Python/numpy interface to netCDF, http: //netcdf4-python.googlecode.com/, 2014.

Winkelmann, R., Martin, M. A., Haseloff, M., Albrecht, T., Bueler, E., Khroulev, C., and Levermann, A.: The Potsdam Parallel Ice Sheet Model (PISM-PIK) - Part 1: Model description, The Cryosphere, 5, 715-726, doi:10.5194/tc-5-715-2011, 2011.

Yoshimori, M., Weaver, A. J., Marshall, S. J., and Clarke, G. K. C.: Glacial termination: sensitivity to orbital and $\mathrm{CO}_{2}$ forcing in a coupled climate system model, Clim. Dynam., 17, 571-588, doi:10.1007/s003820000134, 2001.

Zweck, C. and Huybrechts, P.: Modeling of the Northern Hemisphere ice sheets during the last glacial cycle and glaciological sensitivity, J. Geophys. Res., 110, D07103, doi:10.1029/2004JD005489, 2005. 